\title{
Insect Amylase-Plant Amylase Inhibitor Interaction is Key to Success of Transgenics Against Insectherbivory
}

\section{Rimaljeet Kaur and Anil Kumar Gupta*}

Department of Biochemistry, Punjab Agricultural University, Ludhiana-141004, India

\section{Commentary}

Amylase is an important digestive enzyme required for the optimal growth and development of insects. They improve insect digestive capacity, help them to survive in diverse conditions and increase their fitness value. Due to their important biochemical role in insect growth and development, when the action of this enzyme is inhibited, insect nutrition is impaired, its growth and development is retarded and eventually death occurs due to starvation. $\alpha$-Amylase inhibitors (AIs) occur as part of natural defense mechanisms against pests by interfering in their digestion process and thus could provide access to new pest management strategies. To be effective, an inhibitor should inhibit the insect enzyme substantially at low concentration and at the $\mathrm{pH}$ found in the insect gut. For instance, amaranth inhibitor shows high inhibition against Hypotheneumushampei a-amylase at alkaline $\mathrm{pH}$. However, maximum complex formation between insect H. hampeiamylase and common bean inhibitors occur around $\mathrm{pH}$ 4.0 to 5.5 and little complex formation occurs at $\mathrm{pH} 7.0$ or higher [1]. Ozguret al [2] observed that Eurygasterintegriceps a-amylase was resistant to inhibition by bean and chickpea amylase inhibitors and only slightly inhibited by wheat and maize amylase inhibitors. These results also indicated the necessity of optimum $\mathrm{pH}$ for the inhibitor to act. The optimum $\mathrm{pH}$ of $E$. integricepsgut $\alpha$-amylase is 6.5 , which is not an optimum $\mathrm{pH}$ for bean inhibitors to act.AIs isolated from various crops such as wheat, Phaseolus vulgaris, Amaranthus, Maize, Tepary bean, Phaseoluscoccineus, Colocasia, pigeon pea little millet, finger millet inhibited several insect amylases [3,4]. They are quite specific to their target enzyme [5]; therefore, a proteinaceous inhibitor that inhibits the activity of one insect amylase may not have the same effect on the other insect amylases. Remarkably, the way the inhibitors interact with catalytic acid groups of the enzymes shows enormous variation. Firstly, binding between the inhibitor and the catalytic site of the enzyme can be either through direct hydrogen bonds or through hydrogen bonds via a water network or a water molecule. The second variation in enzyme-inhibitor complex involves a fully hydrated $\mathrm{Ca}^{+2}$ at the protein interface [6]. For example, AIs of common bean and ragi inhibits amylase by direct hydrogen bonding while amaranthus and barley inhibitors causes the inhibition through catalytic acid contacts via water and catalytic acid contacts via water-calcium-water network, respectively. Due to great diversity of AIs and their expressive specificity variability, these could be used according to their effectiveness against target enzymes. Genes encoding $\alpha$-amylase inhibitors can be employed for the development of transgenic plants to confer resistance against insect pests.

The production of transgenic plants expressing AIs is an attractive and alternative ecofriendly approach in comparison to the use of chemical pesticides and insecticides that could contribute in developing resistant crop varieties to their major target insect pests. However, certain considerations should be taken into account while highlighting AIs as promising candidates for targeting specific amylase. They must not interfere with the action of endogenous plant amylases, which are involved in germination and should also lack the activity against mammalian enzymes, although this is in general a lesser issue as cooking would denature any inhibitors before ingestion. AI should show maximum interaction with insect amylase at gut pH.Hardly any emphasis has been made on the action of insect proteases on plant AIs for developing transgenics with AI. AI resistant to the action of insect gut proteases could be better candidate for insect resistant transgenics.

The first demonstration involving AIs used was that of AI-1 from a common bean that specifically inhibited amylases of three bruchids; the pea weevil Bruchuspisorum, the cowpea weevil and the azuki bean weevil [7]. The transgenic pea plants caused almost complete larval mortality of the first or second instars as demonstrated by insect bioassays as well as under field conditions. The transgenic azuki bean plants expressing common bean AI-1 were completely resistant to the azuki bean weevil. However, AI-2 was partially effective in protecting field-grown transgenic peas against pea weevils. Nevertheless, in feeding tests the transgenic pea plants expressing AI-2 showed complete effectiveness against Zabrotessubfasciatus. Thus, the determination of structural features of amylases and amylase inhibitors of different orders, specificity of AIs can provide better insights in depicting variability during complex formation and could promote the production of transgenic crops against particular insect pest. Biochemical evaluation will play an important role in searching AIs with desirable characteristics for the success of transgenics so produced.

\section{References}

1. Valencia A, Bustillo AE, Ossa GE, Chrispeels MJ (2000) a-Amylases of the coffee berry borer (Hypothenemushampei) and their inhibition by two plant amylase inhibitors. Insect Biochemistry and Molecular Biology 30: 207-213.

2. Ozgur E, Yucel M, Oktem HA (2009) Identification and characterization of hydrolytic enzymes from the midgut of Sunn Pest of wheat (Eurygasterintegriceps). International Journal of Pest Management 55: 359364.

3. Kaur R, Gupta AK, Taggar GK (2015) Characterization and inhibition studies of Helicoverpaarmigera (Hubner) gut $\alpha$-amylase. Pest Managemant Science 71: $1228-1237$

4. Kumari B, Sharma P, Nath AK (2012) a-Amylase inhibitor in local Himalyan collections of Colocasia: Isolation, purification, characterization and selectivity towards $\alpha$-amylases from various sources. Pesticide Biochemistry and Physiology 103: 49-55.

*Corresponding author: Anil Kumar Gupta, Department of Biochemistry, Punjab Agricultural University, Ludhiana-141004, India; E-mail: anilkgupta1954@gmail.com

Received: July 13, 2015; Accepted: July 24, 2015; Published July 27, 2015

Citation: Kaur R, Gupta AK (2015) Insect Amylase-Plant Amylase Inhibitor Interaction is Key to Success of Transgenics Against Insectherbivory. Biochem Anal Biochem 4: 201. doi:10.4172/2161-1009.1000201

Copyright: (c) 2015 Kaur R, et al. This is an open-access article distributed under the terms of the Creative Commons Attribution License, which permits unrestricted use, distribution, and reproduction in any medium, provided the original author and source are credited. 
Citation: Kaur R, Gupta AK (2015) Insect Amylase-Plant Amylase Inhibitor Interaction is Key to Success of Transgenics Against Insectherbivory. Biochem Anal Biochem 4: 201. doi:10.4172/2161-1009.1000201

Page 2 of 2

5. Kaur R, Gupta AK, Taggar GK (2014) Structural features, substrate specificity, kinetic properties of insect a-amylase and specificity of plant a-amylase inhibitors. Pesticide Biochemistry and Physiology 116: 83-93.

6. Svensson B, Fukuda K, Nielsen PK, Bonsaqer BC (2004) Proteinaceous alphaamylase inhibitors. Biochimicaet Biophysica Acta 1696: 145-156.
7. Schroeder HE, Gollash S, Moore A (1995) Bean a-amylase-inhibitor confers resistance to the pea weevil (Bruchuspisorum) in transgenic peas (PisumsativumL). Plant Physiology 107: 1233-1239. 